\title{
Evaluation of the Implementation of Community-Based Water Supply and Sanitation Programs in Cihara Village, Lebak Regency
}

\author{
Dini Ulfah Dianingsih ${ }^{1 *}(\mathrm{D})$, Rina Yulianti ${ }^{2}$, Hasuri Waseh ${ }^{3}$ (iD \\ 1,2,3 Department of Public Administration Studies, Faculty of Social and Political Sciences, \\ Universitas Sultan Ageng Tirtayasa
}

*Correspondence : rina.yulianti@untirta.ac.id

\section{ARTICLE INFO}

\section{Article History}

Submited; May 18, 2021

Revised; June 14, 2021

Accepted; June 30, 2021

Available online: July 08,2021

\section{Keyword}

Evaluation

Implmentation

Sanitation

Village

\begin{abstract}
This study aims to evaluate the implementation of Community Based Drinking Water and Sanitation III in Cihara Village, Cihara District, Lebak Regency. The theory used is the evaluation theory by Dunn (2003:610), namely effectiveness, efficiency, adequacy, equity, responsiveness, and accuracy. The method used is descriptive with a qualitative approach which will be analyzed in depth according to the existing phenomenon, the phenomenon referred to in the case study of community-based drinking water and sanitation. The results showed that the implementation of the PAMSIMAS III program in Cihara Village, Cihara District, Lebak Regency had not run optimally. Suggestions that become recommendations for supervision from relevant agencies after the construction of facilities are completed and there are efforts from relevant agencies or stakeholders to provide awareness to the community about the importance of PHBS, community self-help groups have a strategy so that the community can participate in the form of in-cash contributions and in deliberation, and the existence of cross-subsidies for infrastructure maintenance fees for economically disadvantaged communities.
\end{abstract}

\section{INTRODUCTION}

The Community-Based Water Supply and Sanitation Program (PAMSIMAS) was originally called WSSLIC (Water Supply and Sanitation for Low Income Communities). The PAMSIMAS program is one of the national programs organized in a structured manner by the Central Government to Local Governments to improve access of rural residents from periurban (suburbs) to proper drinking water and sanitation facilities with a community-based approach (Arsyad, 2010). The implementation of this program is to support the achievement of the MDGs targets (drinking water and sanitation sector) through the mainstreaming and expansion of community-based development approaches. The PAMSIMAS I Program was implemented in 2008-2012, then the PAMSIMAS II Program was implemented in 2012-2015, and the PAMSIMAS III Program which was implemented in 2016-2019, a continuation of the PAMSIMAS Program I and II, is an instrument for implementing two national agendas aimed at population coverage of adequate and sustainable drinking water and sanitation services, 
namely (1) 100\%-100\% access to drinking water and sanitation, and (2) Community-Based Total Sanitation (STBM).

In order to continue the success of achieving the Millennium Development Goals target for the Water and Sanitation sector (WSS-MDG) (Sustainable Development Goals, 2019), the Government of Indonesia launched the national program for Universal Access to Drinking Water and Sanitation in 2019 with the target of achieving 100\% access to drinking water and sanitation. for the entire population of Indonesia with a legal umbrella in the form of Presidential Regulation Number 5 of 2015 concerning the 2015-2019 National Medium-Term Development Plan [RPJMN]. The Community-Based Water Supply and Sanitation Program aims to increase community access to sustainable drinking water and sanitation services in rural and peri-urban areas. In order to ensure the effectiveness of the implementation of community-based drinking water and sanitation programs, the government through the Decree of the Director General of Human Settlements Number: 35/KPTS/DC/2017 and Number: 91/KPTS/DC/2017 concerning Determination of Target Villages for Drinking Water Supply Programs and Community-Based Sanitation for Fiscal Year 2017 Phases I and II.

Based on the SECOND Dictum of the Decree of the Director General of Human Settlements Number 35/KTPS/DC/2017 concerning Determination of Target Villages for the Community-Based Drinking Water and Sanitation Provision Program for Fiscal Year 2017 Phase I, villages that have not been established in the PAMSIMAS III Program of 2017 will be determined later after the proposed name The target village submitted by the Regent to the Director General of Human Settlements has been verified for conformity with the PAMSIMAS village selection criteria. The placement of the target districts is carried out by the Central Government based on the interests of the Regional Government, while the selection of the target Villages is carried out by the Regional Government. The target of the PAMSIMAS Program target villages is approximately 3,401 villages. The places for the implementation of the PAMSIMAS Program in Banten can be seen in table 1.1 below:

\begin{tabular}{|l|l|c|c|}
\hline NO & Regency/City & Village & $\begin{array}{c}\text { Budget Allocation } \\
\text { BLM (Rp) }\end{array}$ \\
\hline 1 & Pandeglang & 12 & $3.920 .000 .000,-$ \\
\hline 2 & Lebak & 15 & $3.904 .760 .000,-$ \\
\hline 3 & Tangerang & 12 & $2.940 .000 .000,-$ \\
\hline 4 & Serang & 16 & $3.920 .000 .000,-$ \\
\hline$\quad$ Amount & $\mathbf{5 5}$ & $\mathbf{1 4 . 6 8 4 . 7 6 0 . 0 0 0 , -}$ \\
\hline
\end{tabular}

Source: Decree of the Director General of Human Settlements, Ministry of Public Works and Public Housing No: 35/KPTS/DC/2017

Lebak Regency is one of the areas that has received a drinking water and sanitation program, because it has problems with clean water, which is focused on Cihara Village, Cihara District. As a stimulant program with a community-based approach, the PAMSIMAS III program places the community as the main actor and at the same time as the person in charge of implementing activities. Cihara Village, Cihara District, is one of the villages that received the PAMSIMAS III program in Lebak Regency. Cihara Village, Cihara Subdistrict, is one of the villages in Lebak Regency that received the PAMSIMAS III program, because the Cihara Village community's access to drinking water is still low and there has never been any facility activity for the community so that it requires SPAM expansion activities.

Activities carried out in its implementation include the construction of clean water facilities, sanitation facilities in elementary schools, empowerment training, health training, technical training, health promotion activities in the community and schools (Samnuzulsari \& Arieta, 2017). The activities that will be carried out are expected to reduce problems in the community, especially in terms of clean water facilities and sanitation facilities. The participation of the parties involved in this program is also very necessary as well as the 
participation and self-reliance of the community. Evaluation of the Implementation of the PAMSIMAS III Program in Cihara Village, Cihara District, Lebak Regency based on observations there are still several shortcomings that can be considered as problems in the evaluation of the implementation of PAMSIMAS III implementation, including the following:

First, the lack of public awareness about the importance of a Clean and Healthy Lifestyle (PHBS). Prior to the PAMSIMAS III program, entering Cihara Village initially carried out activities in the river, dug wells in the rice fields, in Balong, in the bushes and in the gardens around the village. Such as bathing, urinating / defecating, washing so that public health can be disrupted and environmental hygiene can be disrupted. Until now, the people of Cihara Village still carry out these bad and unhealthy activities or habits. Second, the monthly payments are not running well, there are still arrears in payments. The success of the implementation of PAMSIMAS III really depends on the participation or contribution of the community. However, there are still people who assume that the PAMSIMAS III building is fully funded by the Government. This results in a lack of contributions in the form of cash (incash) and materials/labor (in-kind).

Third, buildings that should be well maintained. However, there is still a lack of public awareness for the maintenance of PAMSIMAS III buildings. So there is a lack of sense of belonging from the community to the water reservoir. Fourth, the lack of openness in management management. This illustrates that the management in Cihara Village shows that there is a lack of communication with each other among fellow administrators in the village. Fifth, the drinking water service provided has begun to decrease, so that the demand for quantity from the community cannot be fulfilled. Because near the location of the water source in Cikopo Village there was mining in 2019 at that location, so the springs in Cihara Village cannot flow to each House Connection (SR).

The results of these observations indicate that the Evaluation of the Implementation of the Community-Based Drinking Water and Sanitation Provision Program (PAMSIMAS) III in Cihara Village, Cihara District, Lebak Regency has not run optimally, especially the lack of public awareness about the importance of a Clean and Healthy Lifestyle (PHBS), the monthly fee is less In progress, there are still arrears in payments, lack of public awareness for maintenance of PAMSIMAS III buildings, lack of openness in management management, and reduced drinking water services in evaluating the implementation of this program so that it can run properly and efficiently. So the implementation is not as expected. Based on the background of the research that has been described, the formulation of the problem to be studied is as follows: How to evaluate the implementation of the Community-Based Water Supply and Sanitation Program (PAMSIMAS) III in Cihara Village, Cihara District, Lebak Regency? Then the purpose of this study was to evaluate the implementation of the Community-Based Water Supply and Sanitation Program (PAMSIMAS) III in Cihara Village, Cihara District, Lebak Regency.

\section{RESEARCH METHODS}

In this study, where researchers want to know how the implementation evaluation process in the field regarding the Community-Based Water Supply and Sanitation Program (PAMSIMAS) III in Cihara Village, Cihara District, Lebak Regency. So that the research entitled Evaluation of Implementation in the field regarding the Community-Based Drinking Water and Sanitation Provision Program (PAMSIMAS) III in Cihara Village, Cihara District, Lebak Regency, used descriptive qualitative research methods. The data collected is in the form of words, pictures, and not numbers (Moleong, 2012). Then the results of research on implementation evaluation are analyzed in depth using existing secondary data (Weimer \& Vining, 2017) based on the analysis of researchers using the concept of policy evaluation.

\section{RESULTS AND DISCUSSION}

PAMSIMAS III is one of the programs for providing drinking water, sanitation, and health. The PAMSIMAS III program is one of the Central Government programs in development that goes to villages to solve all problems related to water and the community-based environment. 
The theory used is the evaluation theory model proposed by (Dunn, 2003) which consists of effectiveness, efficiency, adequacy, equity, responsiveness, and accuracy.

\section{Effectiveness}

On the dimension of effectiveness in the implementation of the Community-Based Water Supply and Sanitation Program (PAMSIMAS) III in Cihara Village, Cihara District, Lebak Regency, it can be concluded that it is not yet effective. There are 4 (four) questions that the researcher determines to analyze the dimensions of effectiveness. First, the desired results from the PAMSIMAS III program carried out in Cihara Village according to the objectives have not been carried out optimally. The purpose of the PAMSIMAS III program is to increase public access to sustainable drinking water and sanitation services in rural and peri-urban areas. From the results of the field findings, researchers show that the PAMSIMAS III program has succeeded in increasing community access to sustainable drinking water and sanitation services in rural and peri-urban areas in accordance with the 5 existing components.

Where in the general guidelines of PAMSIMAS III, the scope of the PAMSIMAS III program includes 5 program components, namely (1) Community empowerment and regional and village institutional development, (2) Improvement of hygienic behavior and sanitation services, (3) Provision of drinking water and public sanitation facilities. , (4) Incentive Grants, and (5) Technical support and program implementation management. In the PAMSIMAS III program, in terms of infrastructure, the need for access to drinking water and proper and sustainable sanitation has been handled by providing drinking water facilities and hand washing facilities to help the community and schools so that the program in terms of infrastructure has handled drinking water and sanitation services. feasible and sustainable.

However, researchers found new findings from observations and interviews, it turns out that apart from the handwashing station (TCT) not functioning, there is still an old habit with the tradition, namely that there are still people who defecate in the wells dug in the fields or gardens around their homes. This causes the behavior of clean and healthy living in Cipunaga Village, Cihara Village is still not good. Second, the implementation of the PAMSIMAS III program in Cipunaga Village, Cihara Village has been in accordance with existing guidelines. According to one informant, his village also complies with the existing guidelines because if it is not appropriate, it will cause problems. The village has implemented according to the existing guidelines because they followed all the directions given and they also know the consequences if they do not implement it according to the guidelines (Widjaja, 2004). However, in Cihara Village, in terms of the size of the development, it is in accordance with the existing provisions.

Third, the implementation time of the infrastructure development of the PAMSIMAS III program in Cihara Village was in accordance with the provisions and there were no delays in development. In accordance with what has been described from the stakeholders that they always monitor the implementation of development so that the development carried out does not pass the predetermined time period (Mahadiansar et al., 2020). Then if the delay occurs, usually only a letter of Addendum to the Cooperation Agreement or additional time is given so that the implementation of development can be completed as soon as possible.

Fourth, obstacles in the implementation of the PAMSIMAS program are a common thing. In the implementation of the PAMSIMAS III program in Cipunaga Village, RT 02 and RT 04 in Cihara Village, according to informants who have interviewed researchers stated that there are no obstacles or obstacles in Cihara Village because the community strongly supports the PAMSIMAS III program, but there are only a few I'm just complaining about the springs because at first the springs were intact since there was a mine excavation and in the dry season the water was slightly reduced.

\section{Efficiency}

In terms of efficiency in the implementation of the Community-Based Water Supply and Sanitation Program (PAMSIMAS) III in Cihara Village, Cihara District, Lebak Regency, it can be concluded that it has been effective. There are 4 (four) questions that the researcher 
determines to analyze the efficiency dimension (Alqahtani, 2016). First, the existing budget in accordance with the needs in the implementation of the PAMSIMAS III program in Cihara Village has been effective. Where in increasing public access to adequate and sustainable drinking water and sanitation services established in the PAMSIMAS III program, the government borrows funds from the Foreign Loan (PHLN) IBRD 8578-ID (International Bank for Recontraction and Development) as stipulated in the Loan agreement. IBRD Credit Agreement Number 8578-ID dated December 31, 2020 regarding the Provision of CommunityBased Drinking Water and Sanitation III. The budget used by PAMSIMAS III relies on 5 sources of funds, namely, the source of foreign loans (PHLN) IBRD Loan 8578-ID (International Bank for Recontraction and Development), APBN, APBD, APBDes and nongovernmental contribution funds. Where the five funds already have their respective uses.

Second, community participation in pre-development deliberations conducted by community self-help groups has been carried out thoroughly. At the initial stage, in the PAMSIMAS III program, prior to construction, the RKM (Community Work Plan) document was formed which contained what infrastructure would be built in a village based on the opinion of the community. So in the deliberation it can be said that it is very important because it is related to the needs of the community in the region. Based on the general guidelines of PAMSIMAS III, there are at least 50 participants who attend the deliberation. The deliberation that took place in Cihara Village, the entire community was invited to the deliberation and quite a number of people participated in the deliberation. The community is also given the opportunity to convey the infrastructure needed in their area so that there is a smooth interaction in the deliberation. Then the Cihara Village community also held a triggering discussion related to clean and healthy living behavior. The community is very enthusiastic because the area will be assisted by the construction of the clean water and sanitation facilities.

Third, the contribution of community infrastructure according to the agreement during the deliberation is quite good. Where all the fees set in Cihara Village are in accordance with the agreement during the deliberation. However, in practice, there are still many people who are difficult to collect and some are in arrears in paying the fees. This is because the condition of the people there economically can be said to be lacking because most of the people there work as farm laborers, fishermen and odd jobs so that their income is uncertain. However, it turns out that it is not only people who are economically disadvantaged who find it difficult to pay, people with economically capable conditions are also less aware of paying these contributions. In addition, the fee does not work because the condition of drinking water services has decreased so that it cannot meet the needs of the community in Cipunaga Village, RT 02 and RT 04, RW 003, Cihara Village.

Fourth, the Community Self-Help Group and the Management Group for Drinking Water and Sanitation Development in Cihara Village participated in the training which had been carried out well. Where in accordance with the flow of the PAMSIMAS III activity stages, the training was held once for KKM which was after the triggering of behavior change and/or follow-up of triggering and once for KP-SPAMS was carried out after construction was completed and IMAS II was after all KKM (Community Self-Help Groups) and KP-SPAMS (Management Group for Drinking Water and Sanitation Management Systems) in Cihara Village have attended the training. The material provided in the training relates to the management group for drinking water and sanitation facilities, health, engineering as well as administration and finance. At that time the implementation was carried out at the Nurul Hidayah Islamic Foundation School, MI Nurul Hidayah Cipunaga, Cihara Village, Cihara District, Lebak Regency for 1 day and at the Marbela Anyer Hotel for 3 days.

\section{Adequacy}

On the dimension of adequacy in the implementation of the Community-Based Water Supply and Sanitation Program (PAMSIMAS) III in Cihara Village, Cihara District, Lebak Regency, it can be concluded that it has been effective. There are 4 (four) questions that the researcher determines to analyze the adequacy dimension. First, the management of the 
Community Self-Help Group and the Management Group for Drinking Water and Sanitation Development in Cihara Village are competent in the implementation of the PAMSIMAS III program as a whole and are responsible for their duties. The performance of KKM and KP. SPAMS in Cihara Village is very good because KKM there is very helpful for residents and always coordinates both with residents and village officials to carry out everything.

Then the performance has also carried out its duties well when there is damage to infrastructure as well as immediately repairing it even though there are people who find it difficult to pay their monthly dues and due to reduced water services the fees are no longer running (Lyden et al., 1968). This is because KP-SPAMS has not been able to mobilize community participation in Cihara Village to be able to maintain and maintain existing infrastructure by paying a fee to maintain the infrastructure. Second, the selection of the management of the Community Self-Sufficiency and Management Group for Water Supply and Sanitation Development in Cihara Village is in accordance with the guidelines and wishes of the community and involves the community. Where the selection of management is carried out by deliberation in accordance with the existing agreement in the presence of the relevant village parties including the community.

Third, there are documents for procedures for using and maintaining infrastructure. In addition, the election of the management from the RT and RW levels was then brought to the kelurahan level and carried out through deliberation so that KKM administrators were able to be responsible for their duties. Fourth, the management of Community Self-Help and Management Groups for Drinking Water and Sanitation Development in Cihara Village have documents related to the implementation instructions and technical instructions for the implementation of the PAMSIMAS III program which has been carried out properly, where KKM and KP-SPAMS also received documents for the implementation of the PAMSIMAS III program and for procedures for managing infrastructure, where the document is made to support their tasks in the PAMSIMAS III program so that they can be more focused.

\section{Equity}

On the dimension of equity in the implementation of the Community-Based Drinking Water and Sanitation Provision Program (PAMSIMAS) III in Cihara Village, Cihara District, Lebak Regency, it can be concluded that it has not been running effectively. There are 3 (three) questions that the researcher determines to analyze the dimension of equity. First, the implementation of the PAMSIMAS III program is right for the people of Cipunaga Village RT 02 and RT 04 RW 003 Cihara Village is right on target, because the location is in accordance with the existing decree. Because the existing decree has gone through problem identification prior to the determination, the villages listed in the decision letter regarding the target villages for the community-based drinking water and sanitation program are indeed villages that require increased access to drinking water and sanitation for the PAMSIMAS III program.

Second, the condition of the people in Cipunaga Village, Cihara Village, which has not been carried out optimally. Where the condition of the people there is still not aware of the maintenance of its infrastructure. They think that the program built by the government must also be maintained by the government, the community is only willing to accept the program without trying to change public awareness to take care of it, there are still those who let the faucet break so the water just flows, they don't pay attention to the pipes around the house so that the pipe catches fire. , and there are still people who defecate in the garden without looking at the behavior of clean and healthy living around their environment (Parsons, 2014).

Third, the community feels justice with the infrastructure that has been built that is fair and equitable which is felt by all people who receive the program in their area. Based on the Decree of the Director General of Human Settlements Number: 35 KPTS/DC/2017 concerning Determination of Target Villages for the 2017 Phase I Community-Based Drinking Water and Sanitation Provision Program in Banten Province, especially in Lebak Regency in 2017-2018 that the implementation of PAMSIMAS III in Cihara Village is carried out in 1 village point with a total handling of $50 \mathrm{SR}$ (House Connections). Although the point of infrastructure development is not at all points, the community feels fair with the infrastructure that has been 
built or provided. Both in Cipunaga Village, RT 02 and RT 04, RW 003, Cihara Village, all the people who received the benefits felt fair with the implementation of the development.

\section{Responsiveness}

On the dimension of responsiveness in the implementation of the Community-Based Drinking Water and Sanitation Provision Program (PAMSIMAS) III in Cihara Village, Cihara District, Lebak Regency, it can be concluded that it has been effective. There are 4 (four) researchers determined to analyze the dimensions of responsiveness according to (Jacobs, 2003). First, the community utilizes all the infrastructure of the PAMSIMAS III program which has been carried out well. Communities in Cipunaga Village RT 02 and RT 04 RW 003 Cihara Village have used drinking water facilities, but for school sanitation infrastructure that is obtained, namely the hand washing place is not used because the water does not flow to the faucet. Then there are still people who defecate in the garden and in the rice fields because they don't have a toilet in their house.

Second, the infrastructure built in Cihara Village is in accordance with the village survey itself. Where the infrastructure built in the PAMSIMAS III program has satisfied the community because the infrastructure built is in accordance with the village survey itself. In the Community Work Plan document in Cihara Village there are proposals based on the identification of problems (IMAS) that arise in the village survey itself and also proposals from the community. Third, the management of the Community Self-Help Group and the Management Group for Drinking Water and Sanitation Development in Cihara Village are open to each other and carry out their duties according to general guidelines. According to one of the informants, the problems in the management have been resolved. In addition, the KKM and KP-SPAMS management have carried out their duties in accordance with the general guidelines contained in the PAMSIMAS III Program.

Fourth, the damage to the infrastructure of the PAMSIMAS III program has been handled quickly and has been done well. Where the damage to infrastructure that occurs is usually immediately handled by the KP-SPAMS in Cihar Village, although there are still people who find it difficult to pay fees and have negative thoughts about KP-SPAMS, besides that, the fees do not run due to uneven water conditions due to reduced drinking water services. the condition of the springs is shrinking.

\section{Accuracy}

Accuracy is concerned with whether the desired outcome or goal is truly useful or beneficial (Dunn, 2008). The construction of infrastructure for the PAMSIMAS III program aims to increase public access to sustainable drinking water and sanitation services in rural and peri-urban areas, because many people in these areas do not have access to proper drinking water and sanitation. There are 2 (two) questions that the researcher poses to analyze the dimension of accuracy. First, the benefits of the PAMSIMAS III program have been able to increase community access to sustainable drinking water and sanitation services in rural and peri-urban areas.

In accordance with the Decree of the Director General of Human Settlements Number: 35 KPTS/DC/2017 concerning Determination of Target Villages for the 2017 Phase I Community-Based Drinking Water and Sanitation Provision Program in Banten Province, especially in Lebak Regency in 2017-2018 that the implementation of Drinking Water and Sanitation Provision Community Based III in Cihara Village was carried out in 1 village point with a total handling of 50 SR (House Connections). Then in 2020 based on interviews with informants that there was an increase in house connections, which increased to $104 \mathrm{SR}$. Second, the PAMSIMAS III Program is a program that is in accordance with the needs of Cihara Village and has met the needs there.

Where with this program the community in 2 RT Kampung Cipunaga recipients of the PAMSIMAS III program was greatly helped in carrying out their activities. So that the PAMSIMAS III program has a very positive impact on the areas that receive the PAMSIMAS III program. This section is the most important part of your article. The analysis or research 
results must be clear and concise. The results should summarize (scientific) findings rather than provide data in great detail. Please highlight any differences between your results or findings and previous publications by other researchers. Each finding must be supported by adequate data and must be able to answer the research questions or hypotheses that have been stated in the introduction.

\section{CONCLUSION}

The final conclusion regarding the Evaluation of the Implementation of the CommunityBased Drinking Water and Sanitation Provision Program (PAMSIMAS) III in Cihara Village, Cihara District, Lebak Regency is still not going well. Based on the results of the study, the researchers concluded that in terms of effectiveness, the PAMSIMAS III program was able to increase access to drinking water for sustainable drinking water and sanitation services in rural and peri-urban areas in Cihara Village, but there are still some people who defecate openly so that awareness the community is still lacking in clean and healthy living behavior (PHBS). Furthermore, in terms of efficiency, the implementation of deliberation in Cihara Village is quite participatory because the community is very enthusiastic because the area has been built with drinking water and sanitation facilities, but the mindset of the community has not changed, thinking that the PAMSIMAS III program is fully funded by the Government.

There are still many people who are difficult to collect and some are in arrears in payment of dues, even though the fees were in accordance with the agreement during the deliberation and did not work because the condition of drinking water services had decreased so that they could not meet the needs of the people in Cipunaga Village RT 02 and RT 04 RW 003 Chara Village. In the aspect of adequacy, the performance of the drinking water and sanitation management system group in the PAMSIMAS III program can be said to be good when there is damage to the KP-SPAMS infrastructure and repair it immediately, it's just that they have not been able to mobilize the community to participate in the maintenance and maintenance of infrastructure by paying a fee. on time because the dues are used for maintenance and care. This is constrained by people whose economic conditions are lacking and drinking water services are reduced.

Equity Aspect, infrastructure development in accordance with the point of community environment that requires increased access to drinking water and sanitation in the provision of drinking water and community-based sanitation (PAMSIMAS) III. As happened in Cipunaga Village, Cihara Village, where the people of Cipunaga Village RT 02 and RT 04 RW 003 are in dire need of proper and sustainable drinking water and sanitation facilities, but there are still people who do not care about the maintenance of their infrastructure and let the faucets are damaged so that the water flows so badly. They just don't pay attention to the existence of pipes around the house so that the pipes catch fire, and there are still people who defecate carelessly into the garden without seeing clean and healthy living behavior around their environment. Responsiveness, the infrastructure in the PAMSIMAS III program that was built and provided has been used by the people of Kampung Cipunaga RT 02 and RT 04 RW 003 Cihara Village such as drinking water facilities that have been used, but for school sanitation infrastructure that is obtained, namely hand washing facilities are not used because the water is not available. flows into the faucet. Then there are still people who defecate in the garden and in the rice fields because they don't have a toilet in their house. In terms of accuracy, the PAMSIMAS III program has been in accordance with the needs of the community in Cihara Village.

\section{REFERENCE}

Alqahtani, K. (2016). Decision oriented evaluation: A review of various models of evaluation. International Journal of Scientific \& Engineering Research, 7(5), 929-931.

Arsyad, S. (2010). Konservasi tanah \& air. IPB Press.

Dunn, W. (2003). Analisis Kebijakan Publik. PT. Prasetia Widia Pratama.

Dunn, W. (2008). Public policy analysis : An introduction (4th ed.). Pearson, Prentice Hall.

Jacobs, C. (2003). Managing organizational responsiveness. DUV. 
Lyden, F. J., Shipman, G. A., Wikinson, R. W., \& LeBreton, P. P. (1968). Decision-flow analysis: A methodology for studying the public policy-making process. Comparative Administrative Theory, 155-168.

Mahadiansar, M., Ikhsan, K., Sentanu, I. G. E. P. S., \& Aspariyana, A. (2020). Paradigma pengembangan model pembangunan nasional Di Indonesia. Jurnal Ilmu Administrasi : Media Pengembangan IImu Dan Praktek Administrasi, 17(1), 77-92. https://doi.org/10.31113/jia.v17i1.550

Moleong, L. J. (2012). Metodelogi penelitian kualitatif. Remaja Rosdakarya.

Parsons, K. (2014). Human thermal environments: The Effects of hot, moderate, and performance (3rd ed.). CRC Press.

Samnuzulsari, T., \& Arieta, S. (2017). Ipteks Bagi Masyarakat: Penguatan Pendidikan di Sekolah (W. E. Yudiatmaja, Ed.). Umrahpress.

Sustainable Development Goals. (2019). Mengenal Apa itu Pengertian Sustainable Development Goals - SDGs 2045. Cloudhost. https://idcloudhost.com/mengenalsustainable-development-goals-sdgs-2045/

Weimer, D. L., \& Vining, A. R. (2017). Policy analysis: Concepts and practice. In Policy Analysis: Concepts and Practice. Taylor and Francis. https://doi.org/10.4324/9781315442129

Widjaja, H. (2004). Otonomi desa: merupakan otonomi yang asli, bulat dan utuh. Rajagrafindo Persada. 